\title{
Indonesia's Responses on Human Rights Violations Against Indonesian Migrant Workers in Hong Kong (2011-2013)
}

\author{
Fahmi Imam Fauzy \\ University of Indonesia \\ Depok, Jakarta \\ fahmiimamfauzy@gmail.com
}

\begin{abstract}
Working abroad is an ordinary phenomenon in Indonesia. It becomes an interesting study in International Relation as globalization develops.

Hong Kong is one of destination countries for Indonesian Migrant Workers since 1990. However, many human rights violations often occurred against the workers. Most of them work in private sector as a domestic worker who are potential to be violated. Most of the violations are early termination of employment, communication cut off, uncertain employment contract, excessive deduction of salary, unpaid wage, torture, and extorting. Even though Hong Kong has the law of manpower on foreign domestic workers, the violation still happen. The total number of violation against Indonesian migrant workers constantly increase during 2011 - 2013. This research finds several responses of Indonesian government toward the issues in finding solutions and maximizing the protection for Indonesian migrant workers in Hong Kong.
\end{abstract}

Theoretically, the research employs the first track of Multitrack Diplomacy in which Indonesia government actively promotes in finding solutions to the issues. This research utilizes qualitative research with descriptive analysis method. It uses qualitative data, gathered from various sources and in depth interviews with Indonesia government representative.

Keywords-Indonesian Migrant Workers (IMW), Hong Kong, Indonesian Government. Human Right Violations

\section{INTRODUCTION}

Working abroad is one of the alternatives to choose considering less of jobs and opportunity in Indonesia. Working in other county is believed as the best strategy to earn financial support and to improve the quality of the family' economy.

At the beginning of the 1890s, the mobilization known as migration phenomenon happened in Asia. Especially for Indonesia, most of the mobilizationwas motivated by economic reason. The number of migration significantly increased. Indonesian Migrant Workers (IMW) widespread to Suriname, New Caledonia, Siam and Sarawak with a total number of 10.000 workers in that time.[1]

Through globalization, people can freely move and travel over the places in the world for multiple reasons. Every destination country competes to promote the potentials and profits of working, such as higher wage, tourism sites (religious site in Middle East region). In addition, Indonesia has six populardestination countries cooperated for years, are Saudi Arabia, Malaysia, Singapore, Hong Kong, Syria, and Taiwan.[2]

Especially Hong Kong, there are two attractiveness that becomes the special reasons for IMW to choose Hong Kong: firstly as a freedom country and as a wellorganized country for foreign workers, and secondly as a place with the highest wage among the six destination countries[2] Nonetheless, the research finds the violations that fully inflicted for IMW, specifically the human rights violations, either physically or non-physically. For instance, early termination of employment contract, communication cut off, uncertain and inconsistent of the employment contract, deduction of wage, unpaid wage, torture, and extorting.[3]

The state must be present in this issue. According to the Indonesian law, government obligates to protect and to ensure the rights of every Indonesian citizenship, including people who are beyond Indonesia territorial. Thus, the research will focus more on how government takes part and responds to the issue of human right violation against the violations of IMW in Hong Kong from 2011 to 2013. The research states that government has diplomatic strategic to cover the IMW, because government can formally push Hong Kong government and communicate with third party to gain the prominent purposes. The cooperation model between Indonesia and Hong Kong in term of foreign migrant workers can be categorized asPrivate to Private ( $\mathrm{P}$ to $\mathrm{P}$ ). Meaning that third party (private agency) has prominent role in placing the IMW.

\section{INDONESIA-HONG KONG RELATIONSHIP ON MIGRANT WORKERS}

Historically, the migration phenomenon has begun since the 1870s from Europe to United Stated of Amerika estimated about 60 million people motivated by expansion and colonization. In the $1890 \mathrm{~s}$, it begun in Indonesia with popular destinations were Suriname and South America;working as a slave under Dutch colonization.[4]

On the other hand, Hong Kong became a popular destination country for IMW in 1985, and increased in the 
1990s. At least 80.000 IMW migrated to Hong Kong, and growth to 16.000 people per years. [5] $\mathrm{P}$ to $\mathrm{P}$ cooperation model is the model which the agency and the employerare private sector. The government's role is only making the mechanism and rules of the placement policy. Both governments (Indonesia and Hong Kong) give direct orders toward the trusted and chosen private agency to place the IMW in Hong Kong.[6]

Hong Kong is the fifth 'favorite' country for the IMW since 2011 to 2013 after Malaysia, Taiwan, Saudi Arabia, and Uni Emirate Arab. Comparing to these states, Hong Kong is the only state that has clear regulation for foreign migrant workers in informal sector, called as the Employment Ordinance. It regulates the rights of employer such as standard minimum wage, working hours, freedom of union and communication, etc.

\section{Table: Placement of Indonesian Migrant Workers in Hongkong (2010-2013)[7]}

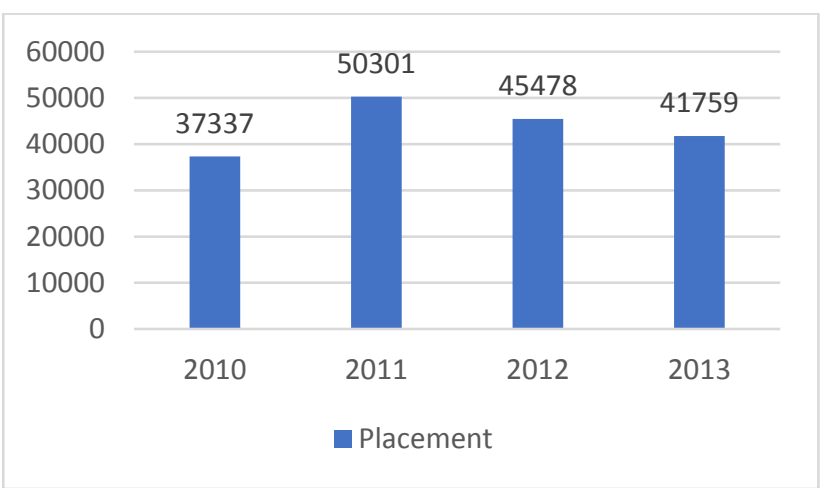

At least there are two fundamental reasons why IMW choose Hong Kong as destination country. First, because of employment ordinance of Hong Kong. Second, the amount of salary which always increases every year.[2] According to the data, the wage of IMW in Hong Kong were 3.740 (HKD)/Rp 4.114 .400 in 2011, 3.920 (HKD)/Rp 4.312.000 in 2012, and 4.010 (HKD)/Rp 6.015.000 in 2013. Comparing to Malaysia is only $\mathrm{Rp}$ 2.700.000 in 2013, Saudi Arabia is Rp 1.500.000-Rp 3.750.000, and Singapore is Rp 4.992.000 in 2013.[5]

It was clear that economic motivation is the best reason in choosing Hong Kong, in which salary in Hong Kong is highest among the other destination countries. Moreover, personal right is also guaranteed by Hong Kong government.

\section{HUMAN RIGHT VIOLATIONS AGAINST IMW IN HONG KONG.}

Hong Kong formally has regulated and implemented the constitution on right and obligation of foreign migrant workers in domestic sector, titled with the Employment Ordinance, and it was amendment in 2010.[8] This regulation gives the advantages for workerswhich attract them to come to the country. They think that this regulation will guarantee their safety in there. This condition in line with the data in the previous table of IMW placement to Hong Kong that the number of placement presented increase from 2010 to 2013.
Nevertheless, the infraction against the rule exists in Hong Kong. The impact is that IMW automatically become the main victim of employer act, motivated by some reasons. The human right violation of the IMW will be described by the following table.

Table: The Number of Human Right Violations Cases against Indonesian Migrant Workers in Hong Kong (2010-2013)[3]

\begin{tabular}{|c|l|c|}
\hline No & \multicolumn{1}{|c|}{ Cases } & Number \\
\hline 1 & $\begin{array}{l}\text { Early Termination of Employment } \\
\text { Contract }\end{array}$ & 29 \\
\hline 2 & Communication Cut off & 18 \\
\hline 3 & $\begin{array}{l}\text { Working beyond employment } \\
\text { contract. }\end{array}$ & 11 \\
\hline 4 & Deduction of Salary & 6 \\
\hline 5 & Unpaid wage & 4 \\
\hline 6 & Torture Total & 7 \\
\hline 7 & Extorting & $\mathbf{7 3}$ \\
\hline
\end{tabular}

The data describe that the various and a total number of Human rights violation toward IMW are 73 cases, with early termination of employment contract as the worst case by 29 cases. Then, the lowest case is the unpaid wage.

Comparing the data cases, the total number of cases relatively fewer than the total placement in 2010 to 2013. But this becomes very important and significant when talking about the human rights as the human right is the basic principle of human being and the basic of life that must be respected by all people including the employer in this case. Moreover, United Nations has decided through the Declaration of Human Rights for people all over the world.

\section{RESPONSES OF INDONESIAN GOVERNMENT TOWARD THE HR VIOLATIONS}

In the last decades, Indonesian government has strongly and actively endeavorto regulate the recruitment and placement of IMW, and innitiate many programs for IMW to access their justice both in Indonesia and destination country. Moreover, the program will also be implemented in other destination country of IMW which the situation in Hong Kong become a background as a prominent base line contributing to the arrangement of Indonesian government policy on IMW.

According to Servulus Bobo Riti, the Sub-director of Asia and Africa Regions of Foreign Relation Directorate of BNP2TKI, stated that Hong Kong situation is better than other destination in term of regulation and wage. It motivates the Indonesian government to arrange the 
regulation that has adjusted to every country condition for other destination countries.[2]

Indonesian government have expanded the obligation for protection through Consulate General of Republic of Indonesia in every destination country, including Hong Kong. It became a historical momentum to take attention toward IMW by ratifying the convention of United Nation of migrant workers.[9]

Regarding the issue of human right violation in Hong Kong, the research finds that Indonesian government through The National Board and Placement and Protection of Indonesia Overseas Workers or BNP2TKI and Consulate General of Republic of Indonesia in Hong Kong has responded with two models of diplomatic strategies; short and long terms of responses.

First, the short-term response of government is making good cooperation and relation with Indonesian trade union. This strategy used because most of IMW are united or gathered in the trade union, considered Hong Kong is cosmopolitan country with free country of foreign migrant workers, and Hong Kong government fully allow this activity for every foreign migrant workers, especially IMW.

Trade unions in Hong Kong are mainly domestic workers who organize them-self to unite and to safeguard their interests. In fact the background of origin country is very dominant, including Indonesian trade union such as Coalition of Indonesian Migrant Workers Organization (KOTKIHO)[10]. For IMW, the function of the trade union is as important as the government's role in term of protection.

According to TeguhHendroPrayono, the Director of Protection National Board of Placement and Protection Indonesia Migrant Workers (BNP2TKI), government gain the information of IMW from the union. This becomes easier to protect the IMW because IMW is personally closer to the union than to the government.[11]

One of the program involving the trade union is the launching ofKartu Tenaga KerjaLuangNegeri (KTKLN) in 2011. This program is to identify the identity of IMW in case the passport was lost, arrested by agencies and employers. Cooperated with KOTKHIHO, the IMW could extend the legality of KTKLN in every year. Moreover, KOTKIHO Consulate General of The Republic of Indonesia in Hong Kong also provides courses and beauty salons for IMW in 2013 which had graduated 150 of IMW.[12, 13]

Second, long term responses were establishing the Indonesian Migrant Workers Crisis Centre both in Hong Kong located in Consulate General of Republic of Indonesia and in Indonesia through BNP2TKI in 2011 and publishing the KTKLN in 2012.

The Indonesian Migrant Crisis Centre was purposed to intensively communication between IMW to government authority in Hong Kong, and Consulate General RI in Hong Kong and government in Indonesia. It was established as most of IMW complains and problems were about the human rights violation which need to be handled intensively and in a long time process.

The main function of IMW Crisis Center is to service and to optimize every complain that comefrom IMW overseas either by phone, SMS, FAX, e-mail, complain form, or direct complain to crisis center in Indonesia. The advantage of IMW Crisis Center is that IMW is easier to complain all their problems and the government is easier to response it, because the flow of information regarding to IMW's complains has been centralized in one institution or organization.

According to HeryPrajitno, Coordinator of Crisis Centre of BNP2TKI convey that, "The main purpose of the establishment of Crisis Center is facilitating and nearing services for the people. Thus, between the government (BNP2TKI) and IMW and his/her families interconnect one and another without any bureaucratic confine". [14]

Other advantage of Crisis Centre is providing list of recommendation for proper agencies and its insurance for every legal IMW. It means that government can protect the IMW before placement time through the agency, including control the agency, then to prevent the infraction of the law of placement to Hong Kong.

At the same long responses, the publication of KTKLN in 2012 becomes the other respond of Indonesian government, called Kartu Tenaga KerjaLuangNegeri (KTKLN).[15] The purpose of the KTKLN is to optimize the control of Indonesian government in recording IMW's data as database to give the services for placement and protection for every IMW orderly, easily, and professionally. Hence, it is easier for the Indonesian government to keeping tracks of overseas workers.

Melvin Jhon Raffles $H$ states that the total of KTKLN published in Hong Kong since 2012-2013 are 87.247 pieces of card, and the total of KTKLN is the total of placement to Hong Kong.[16]

\section{CONCLUSION}

To conclude, the placement of IMW in Hong Kong does not equal to the quality of protection rom the employer. The data above shows that the violation of rights toward IMW still exists, thus the role of Indonesia government is important to protect them either diplomatically or nondiplomatically. Several programs have been implemented such as making good communication through cooperation form with trade union in Hong Kong, called as short-term responses. Then, Indonesia government establish the crisis center of IMW located in Consulate General of RI in Hong Kong, and publish the identity card of IMW named KTKLN. These all programs are purposed to protect every IMW without any distinction where IMW from. It means Indonesia actively upgrade its efforts in giving the protection for IMW. 


\section{References}

[1.] Syafaat, Rahman., Menggagas Kebijakan Pro TKI: Model Kebijakan Perlindungan TKI ke Luar Negeri di Kabupaten Blitar. 2002, Malang: Law and Gender Development Centre.

[2]. Personal Interview with Servulus Bobo Riti. 2014: Jakarta.

[3]. The National Board for Placement and Protection of The Indonesia Overseas Workers (BNP2TKI), Data Pengaduan Berdasarkan Negara: Hong Kong. 2013, Research Development and Information Center (PUSLITFO-BNP2TKI): Jakarta.

[4]. Pigay, Natalis, Migrasi Tenaga Kerja Internasional. 2005, Jakarta: Oustaka Sinar Harapan.

[5]. The National Board for Placement and Protection of The Indonesia Overseas Workers (BNP2TKI), Laporan Akuntabilitas Kinerja Instansi Pemerintah Tahun 2012. 2012, The National Board for Placement and Protection of The Indonesia Overseas Workers (BNP2TKI) Jakarta.

[6.] Asian Migrant Centre (AMC), Indonesia Migrant Worker Union, The Hong Kong Koalition of Indonesian Workers Organization (KOTKIHO), Underpayment 2. 2007, AMC, IMWU, Kotkiho: Hong Kong. p. 18.

[7]. The National Board for Placement and Protection of The Indonesia Overseas Workers. (BNP2TKI), Data Penempatan dan Perlindungan Tenaga Kerja Indonesia Tahun 2013. 2013, Research Development and Information Center (PUSLITFO-BNP2TKI): Jakarta.

[8]. Hong Kong Departement of Labong, A Concise to the Employment Ordinance H.K.L. Departement, Editor. 2010: Hong Kong.

[9]. Bassina Farbenblum, Eleanor Taylor-Nicholson, Sarah Paoletti, Akses Buruh Migran Terhadap Keadilan di Negara Asal: Studi Kasus Indonesia. 2013, New York: Open Society Foundations.

[10.] John Benson and Ying Zhu, Trade Union in Asia An Economic and Sociological Analysis 2008, New York: Routledge.

[11]. Personal Interview with Prayono, Teguh Hendro Prayono. 2014: Jakarta.

[12.] Citizen6 Hong Kong. Jumhur: KJRI Hongkong Buka Pelayanan KTKLN untuk TKI. 2013 [cited 2015 February 16]; Available from: http://citizen6.liputan6.com/read/759125/jumhur-kjrihongkong-buka-pelayanan-ktkln-untuk-tki. .

[13]. Kemlu RI, KJRI Hong Kong dan KOTKIHO Wisuda Lulusan Kursus Salon bagi TKI Hong Kong. 2013 [cited 2015 February 16]; Available from: http://www.kemlu.go.id/hongkong/Lists/EmbassiesNe ws/DispForm.aspx?ID=146\&ContentTypeId=0x01005 74B2B380123F5488597FB3B64A2C806. .

[14.] BNP2TKI. Crisis Centre BNP2TKI Selesaikan 66,54 Persen Layanan Pengaduan. 2011 [cited 2014 December 20]; Available from: http://www.bnp2tki.go.id/read/9758/Crisis-CenterBNP2TKI-Selesaikan-6654-Persen-LayananPengaduan-.

[15.] Pikiran Rakyat, KJRI Hongkong Siap Buka Pelayanan KTKLN. 2013 [cited 2015 April 1]; Available from: http://www.pikiran-rakyat.com/node/260388.

[16.] Personal Intervie with Melvin John Raffless H. 2014. 